\title{
ПРОБЛЕМЫ И ПЕРСПЕКТИВЫ ВНЕДРЕНИЯ ВЫСОКИХ ТЕХНОЛОГИЙ В МЕЖОТРАСЛЕВЫЕ СРЕДСТВА ПРОТИВОДЕЙСТВИЯ ПРЕСТУПНОСТИ
}

\author{
Гармаев Ю.П.
}

Аннотация. В статье, с учетом положений «Основ государственной политики Российской Федерации в сфрере развития правовой грамотности и правосознания граждан», рассматриваются перспективы формирования и внедрения межоотраслевых мультимедийных научных разработок по вопросам предупреждения преступности, с применением современных информационных и Интернет-технологий. Рассматриваются также некоторые причины отставания наук антикриминального цикла от нужд практики. На примере научных рекомендаций по противодействию преступлениям несовершеннолетних предлагается расширять круг «конечных потребителей» соответствующих научных продуктов, считать приоритетным внедрение прикладных межоотраслевых мультимедийных разработок типа кратких памяток, руководств и программ на основе популярных компьютерных операчионных систем. С использованием анализа и классификации выделены определены основные проблемы информационного обеспечения деятельности органов и лии, осуществляющих раскрытие и расследование преступлений. Внедрение в науки антикриминального иикла не просто направления, а некой парадигмы приоритета создания прикладных разноотраслевых мультимедийных разработок типа кратких памяток, руководств и программ, соответствующее уточнение кониептуальных подходов к формированию и представлению учебных и практических рекомендаций, к обучению различных потенциальных потребителей - все это позволит сделать важный шаг к сближению науки с практикой, кмодернизации наук антикриминального цикла и приведет к повышению эффективности правоприменения, к росту правосознания населения.

Ключевые слова: Противодействие преступности, высокие технологии, уголовное право, криминалистика, криминология, мультимедийные средства, предупреждение преступлений, прикладные исследования, преступность несовершеннолетних., преступность.

В Основах государственной политики Российской Федерации в сфере развития правовой грамотности и правосознания граждан, утвержденных Президентом РФ 4 мая 2011 г. в числе мер этой политики названо «... распространение в электронных и печатных средствах массовой информации, в эфирном и кабельном вещании теле- и радиоканалов, созданных с государствен- ным участием, в сегменте социальной рекламы, в сети Интернет информационной продукции, содержащей правовую информацию, а также способствующей развитию правовой грамотности и правосознания граждан и пропагандирующей законопослушание, добросовестность в осуществлении прав и выполнении обязанностей, уважительное и бережное отношение к правам 
и охраняемым законом интересам...» (подпункт 1 пункта 19).

В тексте документа используется следующая характеристика информационной продукции: «... доступность для непрофессионального восприятия информационных материалов, предоставляющих базовые юридические знания и формирующих правовую культуру и правосознание граждан (подпункт 2 пункта 19).

Разработкой и внедрением подобного рода «информационной продукции» вероятно должны заняться и юридические науки. Между тем, ни для кого не секрет, что в адрес всех этих наук все чаще раздаются критические замечания, связанные с их отставанием от потребностей практики. «В России, как и в некоторых других государствах, наблюдается излишняя теоретизированность юридических научных исследований, и практики в этом неоднократно совершенно справедливо упрекали теоретиков. По сути дела, получается, что наука, призванная помогать практическому работнику в его повседневной деятельности, отстраняется от своих обязанностей, и практики вынуждены довольствоваться теми уже давно устаревшими моделями, что у них есть. Можно сказать, что наука существует ради науки» ${ }^{1}$. Дисциплины антикриминального цикла, к сожалению, исключением не являются.

Часть 1 статьи 44 Конституции РФ гарантирует каждому свободу научного творчества и преподавания. Надлежащим ли образом представители наших наук воспользовались данной свободой?

Здесь налицо ряд проблем. Не претендую на полноту охвата, отмечу лишь некоторые из них:

Ненадлежащее взаимодействие наук. Недостаточность подлинно междисциплинарных исследований: на стыке уголовно-правовых, криминологических, уголовно-процессуальных, криминалистических и иных.

Неоправданная узость круга «конечных потребителей» соответствующих научных положений и разрабатываемых на их основе рекомендаций.

Сложность и многословность языка изложения большинства «продуктов» наук — научных изданий.

Отставание этих «продуктов» от современных достижений научно-технического прогресса

\footnotetext{
${ }^{1}$ Вележев С.С. Консолидация теории и практики в решении проблем, связанных с юридической ответственностью и наказанием // Администратор суда._-2011.—№ 1.—C. 7-8.
}

в плане, как минимум, формы изложения, средств и методов доведения, доставки знаний до «конечного потребителя».

Рассмотрим обозначенные проблемы более подробно.

1. Ненадлежащее взаимодействие наук. Недостаточность междисциплинарных прикладных исследований. Насколько очевидно то, что следователь, прокурор, судья в своей ежедневной практике не могут разделить свою мыслительную деятельность (и правоприменение) на уголовно-правовую, уголовно-процессуальную и криминалистическую составляющую, настолько и очевидна необходимость разработки и внедрения соответствующих рекомендаций по принципу «разноотраслевое в одном».

Что же делается в междисциплинарном направлении представителями наук антикриминального цикла? Смею предположить, что не так уж и много. Довольно редки индивидуальные и коллективные работы типа: «Квалификация и расследование преступлений...». «Преступления в сфере...: уголовно-правовая, криминологическая и криминалистическая характеристика, методика расследования...». Еще реже встречаются разработки, охватывающие рекомендации большего количества наук (уголовного процесса, оперативно-розыскной деятельности, адвокатской деятельности, и др.). Качество и практическая значимость подобных изданий - проблема отдельная. Зачастую мы видим просто раздельное представление разноотраслевых глав, параграфов в одной книге. И порой создается впечатление, что авторы соседствующих параграфов не то что не вникали - даже не читали труд своего коллеги - представителя другой науки. Не только практика, но и методология формирования подлинно межотраслевых прикладных рекомендаций до настоящего времени не разработана.

В плане взаимодействия наук в учебных и иных изданиях, например, по уголовному праву видим высказывания в том смысле, что данная наука взаимодействует, в частности, с криминалистикой в вопросах выявления виновных лиц, установления конкретных причин и условий совершения преступления, определения причинно-следственной связи между общественно опасным деянием и последствиями и др. ${ }^{2}$. Но как

\footnotetext{
2 Уголовное право Российской Федерации. Общая часть: Учебник для вузов / под ред. В.С. Комиссарова, Н.Е. Крыловой, И.М. Тяжковой.—М.: «Статут».—2012.— C. 12 .
} 
взаимодействует? В каком смысле? На основе какой методологии?

В большинстве учебных изданий по криминалистике, иных публикациях выделяются положения о связи и соотношении этой науки с другими юридическими науками, прежде всего, антикриминального цикла. Не углубляясь глубоко в анализ научных мнений, можно резюмировать, что большинство авторов:

- отмечают, что связь криминалистики наиболее тесна и устойчива с науками уголовного права и уголовного процесса. Причем, в отношении уголовного права речь идет в основном о взаимосвязи криминалистических средств, приемов и методов с уголовноправовой характеристикой преступлений ${ }^{1}$.

- редко анализируют взаимосвязи криминалистики с криминологией, а если соответствующий анализ и производится, то взаимосвязи обозначаются лишь в самом общем виде: «Криминалистика, например, руководствуется сведениями о динамике преступности в конкретном регионе, которые обобщает криминология, для разработки собственных профилактических и предупредительных мер. Так, увеличение числа квартирных краж в том или ином районе является основанием для расширения и централизации систем сигнализации, разрабатываемых криминалистикой» ${ }^{2}$.

- больше внимания уделяют вопросам отграничения наук, нежели вопросам координации, взаимообогащения. Например, часто мы читаем: «... криминология и криминалистика изучают разные объективные закономерности и совпадения в этой части их предметов отсутствует» ${ }^{3}$ И далее следует подробное обоснование различий, как будто криминалистов больше интересует то, чтобы «конкуренты не помышляли заходить каждый на чужое поле», нежели интеграция наук.

В этих условиях, на наш взгляд, страдают интересы всех наук антикриминального цикла,

\footnotetext{
${ }^{1}$ Смахтин Е.В. Криминалистика в системе юридических наук уголовно-правового цикла: теория и практика: Дисс... доктора юрид. наук. 12.00.09.— Тюмень. 2010.— С. 15.

2 Эксархопуло А. А. Криминалистика: Учебник.-СПб.,2009.- C. 45.

${ }^{3}$ Белкин Р.С. Курс криминалистики: учеб. пособие для вузов.-3-е изд., доп.- М.: ЮНИТИ-ДАНА, Закон и право, 2001.- C. 114-115.
}

а главное - практика противодействия преступности.

2. Узость круга «конечных потребителей» соответствующих научных положений и разрабатываемых на их основе рекомендаций. Здесь отметим лишь упущения, некие недоработки в рамках криминалистических исследований. В России и других странах Содружества независимых государств (СНГ) принято считать устоявшимся мнение о том, что в настоящий момент криминалистика, ее средства, приемы и методы успешно используются в иных сферах (оперативнорозыскной, судебной, прокурорской, экспертной, адвокатской деятельности) либо позволяют устанавливать факты, лежащие вне уголовно-правовых явлений (использование криминалистических знаний в гражданском, арбитражном (хозяйственном) или административном процессах) ${ }^{4}$. Отмеченные тенденции позволили нашим ученым-криминалистам закономерным образом констатировать особый междисциплинарный статус криминалистики в ряду юридических наук и учебных дисциплин ${ }^{5}$.

Мнения вполне справедливые, но в основном на теоретико-методологическом уровне. На уровне прикладном соответствующие разработки пока достаточно редки. Большинство же этих самых прикладных рекомендаций, заметим, не только криминалистических, но и уголовно-правовых, криминологических, иных, адресованы, условно говоря, «традиционным конечным потребителям»:

- следственным, иным правоохранительным органам;

- судебным органам и адвокатскому сообществу;

- законодателям и разработчикам законопроектов;

- и, к счастью или к сожалению, - самим ученым, от студента-исследователя до професcopa.

Возьмем для примера исследования в рамках криминалистического обеспечения (криминали-

\footnotetext{
${ }^{4}$ См., например: Шепитько В. Ю. Криминалистика XXI век a: предмет познания, задачи и тенденции в новых условиях // Современное состояние и развитие криминалистики. Сб. науч. трудов / Под ред. Н. П. Яблокова и В. Ю. Шепитько.Х.: «Апостиль», 2012.- С. 43.

${ }^{5}$ См., например: Ищенко Е.П., Жижина М.В. Современные представления о предмете науки криминалистики // Ситуационный подход в юридической науке и правоприменительной деятельности: Мат-лы межд. науч. — практ. конф. / под ред. Т. С. Волчецкой. - Калининград: Изд-во БФУ имени И. Канта, 2012.- С. 62.
} 
стических методик) борьбы с преступлениями несовершеннолетних и в отношении них. Большая часть работ традиционно адресована следователям и иным представителям стороны обвинения в уголовном процессе, реже - судьям ${ }^{1}$. Между тем, очевидно, что соответствующие криминалистические разработки могут и должны быть специально адресованы, как минимум, еще и органам, учреждениям, занимающимся несовершеннолетними, а таковых только в России, только на федеральном уровне насчитывается 19 организаций.

Полагал бы, что наука криминалистика, а также уголовное право и криминология, должны активнее работать и на иных, назовем их «нетрадиционными», субъектов, «конечных потребителей» научных положений и рекомендаций. Это могут и должны быть, например:

- сами несовершеннолетние: как подозреваемые, обвиняемые, привлекаемые к административной ответственности, так и потерпевшие от преступлений, пострадавшие от иных правонарушений, а также потенциально могущие стать и теми, и другими;

шеннолетних;

- $\quad$ педагоги, учителя, тренеры спортивных секций, руководители кружков по интересам, иные взрослые, занимающиеся воспитанием этих лиц;

- работники вышеназванных органов и учреждений, но не только и не столько как их представители, а как практические работники, правоприменители, живые люди со своими особенностями восприятия информации, сильно ограниченные во времени, с разным, далеко не всегда юридическим образованием, способностями к самообразованию, познавательной деятельности вообще и т.д.;

3. Сложность и многословность языка изложения большинства «продуктов» наук — на-

\footnotetext{
${ }^{1}$ См.: например: Макаренко И. А. Криминалист ическое учение о личности несовершеннолетнего обвиняемого: Дис. ... доктора юр. наук. 12.00.09.Саратов, 2007, Подольный Н. А. Теоретические и практические основы раскрытия и расследования преступлений, совершённых молодёжными организованными группировками: Дис. ... доктора юр. наук: 12.00.09.- М, 2008. Гвоздева И.С. Использование специальных знаний при расследовании групповых корыстно-насильственных преступлений несовершеннолетних: Дис. ... канд. юр. наук: 12.00.09.- М, 2008, Третьяков Ю.С. Процессуальные и тактические основы рассмотрения дел о преступлениях несовершеннолетних мировым судьей: Дис. ... канд. юр. наук: 12.00.09.- M, 2009 и другие.
}

учных публикаций. Не считаю корректным оценивать состояние всех наук антикриминального цикла, но в отношении криминалистики следует констатировать, что большинство ее, казалось бы, прикладных разработок все еще характеризуется многословностью, сложностью языка изложения, порой безудержным и малооправданным теоретизированием. Проблема не нова. Еще в 80-х годах прошлого столетия авторитетные российские ученые признавались в том, что многие криминалистические рекомендации написаны тяжелым языком, страдают многословностью, излишней описательностью, насыщены полемикой с другими авторами, имеют многочисленные отклонения от основной темы ${ }^{2}$. Применительно к методикам расследования А. А. Эйсман верно отмечал: «Стремление сообщить в пособии как можно больше сведений и дать как можно больше советов по всем аспектам расследования делает почти бесполезной книгу в глазах практика-профессионала: ему обычно нужна лишь небольшая часть этой информации, а отыскать ее оказывается трудным и длительным делом» ${ }^{3}$.

4. Отставание «продуктов» наук антикриминального цикла от современных достижений научно-технического прогресса в плане формы изложения, средств и методов доведения, доставки знаний до «конечного потребителя».

Опять же еще в прошлом веке отдельные ученые-энтузиасты вполне успешно разрабатывали и внедряли в учебный процесс вузов и в правоприменительную практику специализированные компьютерные программы, например, по анализу исходной информации, выдвижению и проверке типовых версий при расследовании преступлений. В частности, можно отметить интересную информационно-поисковую систему «Полюс-1» (Н. Б. Бобрынин, А. Ф. Лубин, 1989 г.).

В начале века нынешнего отдельные исследователи, в частности, А.С. Шаталов, предприняли попытки разработать целостную теорию криминалистических алгоритмов и программ. Исходили из принципиально верного положения о том, что на современном этапе развития криминалистических методических рекомендаций для практических работников наиболее важны-

\footnotetext{
${ }^{2}$ См., например: Соя-Серко Л. А. Программирование расследования // Социалистическая законность. 1980. № 1. С. 50-51.

3 Эйсман А.А. Теоретические вопросы программирования расследования // Вопросы борьбы с преступностью. Вып. 45. М., 1987. C. $84-85$.
} 
ми их качествами, наряду с полнотой, являются компактность и понятность ${ }^{1}$. Можно было бы добавить еще и такие желаемые качества, как доступность, интерактивность, наконец - привлекательность для потребителя хотя бы на стадии принятия решения об изучении, на уровне так называемого «пользовательского интерфейса»².

Положительные сдвиги, безусловно, есть. Но, что весьма показательно - не столько в среде научной, сколько в практической. Так, Главным управлением криминалистики Следственного комитета РФ (ГУ криминалистики СК РФ) была разработана и внедрена в настоящий момент почти во все территориальные следственные органы инновационная компьютерная программа «Виртуальный осмотр места происшествия: Учебно-методический комплекс», предназначенная для создания интерактивных трехмерных моделей различных мест происшествий, а также для проведения виртуального осмотра места происшествия. Данная программа, помимо правоохранительных органов, рекомендована к использованию в преподавании криминалистики в Московский государственный университет им. М.В.Ломоносова, Московский государственный юридический университет имени О. Е. Кутафина, Уральскую государственную юридическую академию (г. Екатеринбург) и в другие ведущие юридические вузы России. Важно отметить, что для подготовки программного обеспечения были привлечены специалисты компании «Фундаментальные системы анализа»³. При этом «форма обуче-

\footnotetext{
${ }^{1}$ Шаталов А.С. Криминалистические алгоритмы и программы. Теория. Проблемы. Прикладные аспекты. (Научное издание) - М., 2000.—C.163.

${ }^{2}$ Интерфе́йс по́льзователя, он же по́льзовательский интерфейс (UI - англ. user interface) — разновидность интерфейсов, в котором одна сторона представлена человеком (пользователем), другая - машиной/устройством. Представляет собой совокупность средств и методов, при помощи которых пользователь взаимодействует с различными, чаще всего сложными, машинами, устройствами и аппаратурой. Весьма часто термин применяется по отношению к компьютерным программам, однако под ним может подразумеваться набор средств, методов и правил взаимодействия любой системы, управляемой человеком. Пример: дисплей электронной книги или планшетного компьютера + набор кнопок и переключателей для настройки / Материал из Википедии. Режим доступа: http://ru.wikipedia.org/wiki Дата обращения: 10.10.2013.
}

3 Подробно об этом см.: Елинский В. И., Ашимов Ф.М. Виртуальный осмотр места происшествия - инновационный метод повышения профессионального мастерства следователей // Российский следователь.№ 4. - 2013.- C. $6-8$. ния, напоминающая компьютерную игру, легко воспринимается молодыми следователями. Нередко обучаемые с увлечением соревнуются между собой на скорость и качество выполнения заданий» ${ }^{4}$. Не менее важным в аспекте предмета настоящей статьи будет отметить направления дальнейшего усовершенствования данного программного продукта. Среди 10 таких направлений авторы-разработчики выделяют: «Создание полнофункциональной мобильной версии программного обеспечения... для коммуникаторов и планшетных компьютеров для операционных систем «Android», «Windows Phone» и «iOS» ${ }^{5}$.

Итак, слава богу, есть энтузиасты-исследователи, пытающиеся восполнить уже не просто тревожное, а близкое к катастрофическому отставание науки от практики и современных достижений научно-технического прогресса. Однако в широких кругах криминалистического научного и вузовского сообщества по-прежнему стараются как бы не замечать очевидных негативных тенденций.

Отметим традиционные формы представления рекомендаций, «конечных продуктов» наук антикриминального цикла.

А) «Бумажные»:

- объемные книги (монографии, пособия, диссертации, учебники, комментарии и т. п.);

- $\quad$ научные статьи, доклады на конференциях и т. п.

- $\quad$ крупные справочные работы, заключения экспертиз, и т.п.

Б) Электронные (несколько реже и зачастую скромнее по полноте содержания изданий):

- $\quad$ книги и иные материалы, специально подготовленные для электронных справочноправовых систем типа «Консультант Плюс: Комментарии законодательства» и для популярных в научной среде электронных ресурсов $^{6}$.

- статьи, интервью и иные выступления в электронных СМИ, социальная реклама и т.п.

- мультимедийные презентации, видео-, аудио выступления с лекциями, на конференциях,

\footnotetext{
${ }^{4}$ Указ. соч.- С. 59.

${ }^{5}$ Указ. соч.- С. 60.

${ }^{6}$ См., например, для криминалистики и уголовно-процессуального права: сайт Международной ассоциации содействия правосудию (МАСП), режим доступа: http://www. iuaj.net; сайт Международной общественной организации «Конгресс Криминалистов» (International Non-Governmental Organization «Criminalists Congress»), режим доступа: http:// crimcongress.com/, и другие Интернет-ресурсы.
} 
круглых столах и т.п. Особенно если соответствующий цифровой контент ${ }^{1}$ не только записан и распространяется на оптических дисках, а вместе с его рекламой выложен в сети Интернет для свободного изучения и скачивания.

Появление последней формы электронных научных «продуктов» - весьма отрадная тенденция, но находится она лишь в начальной стадии своего развития ${ }^{2}$.

С большим сожалением, но все же следует констатировать, что перечисленные выше «традиционные», но особенно «нетрадиционные» потребители научно-прикладных рекомендаций все меньше и реже читают и используют «бумажные продукты» из перечня «А». Для этого не хватает ни желания, ни времени. К тому же чаще всего быстро найти нужную рекомендацию в толстом бумажном фолианте намного труднее, чем, например, в электронной книге. А вот ассортимент и объем информации, усваиваемой из перечня «Б», растет ежегодно в разы.

Необходимо особо подчеркнуть, что автор этих строк отнюдь не противник теоретических фундаментальных исследований, изложенных на традиционных бумажных носителях. Без таких исследований невозможно поступательное, эволюционное развитие общества и государства. С учетом кризисных явлений в экономике фундаментальные разработки особо уязвимы, поскольку должны поддерживаться и финансироваться, прежде всего, государством. Мы не вправе забывать аксиому: «Нет ничего практичнее хорошей теории»!

\footnotetext{
${ }^{1}$ Контент - (от английского content - содержание) - это любое информационно значимое либо содержательное наполнение информационного ресурса или веб-сайта. Контентом называются тексты, мультимедиа, графика. Однако чаще всего контентом называют текстовое наполнение веб-сайта. Под мобильным контентом подразумевают цифровой контент, который адресован владельцам мобильных устройств. / Материал из Википедии. Режим доступа: http://ru.wikipedia.org/wiki Дата обращения: 10.10.2013.

${ }^{2}$ См., например: Боровских Р.Н. Актуальные проблемы противодействия преступлениям в сфере страхования в России. Видеолекция / Сайт Международной ассоциации содействия правосудию (МАСП). Режим доступа: http:// www.iuaj.net/node/1325. Дата обращения: 11.10.2013.

3 Этот знаменитый афоризм приписывают многим авторам, от Иммануила Канта до Альберта Эйнштейна. Однако есть убедительные доказательства того, что авторство принадлежит знаменитому физику 19 века Густаву Кирхгофу, как перевод с немецкого его фразы: «Eine gute Theorie ist das Praktischste was es gibt».
}

В то же время нет никаких противоречий в том, что наряду с важностью фундаментальной науки, в настоящее время особо востребованы краткие прикладные рекомендации в виде памяток ${ }^{4}$, специальных программных продуктов, особенно в виде мобильных приложений в телефонах, коммуникаторах, планшетных (равно как и стационарных) компьютерах, нетбуках и ультрабуках. Эти продукты научно-технического прогресса сейчас пока весьма немногочисленны, но пользуются повышенным спросом. И спрос этот обречен на постоянный, причем бурный рост. Однако вновь скорбим: науки антикриминального цикла пока не демонстрируют большого интереса к этим перспективным новинкам. Работаем, как говорится, в основном по старинке через традиционную «бумажную» продукцию.

Нам, представителям научного юридического сообщества, разработчикам соответствующих рекомендаций, пора признать, что многие наши коллеги больше склонны теоретизировать, а также критиковать законодателя и разочаровываться в правоприменителе, нежели замечать и изживать признаки собственного догматизма, консерватизма, а порой и просто - непрофессионализма. «В чужом глазу соринку видим, в своем бревна не замечаем» - известная российская пословица применима далеко не ко всем, но ко многим представителям юридической науки.

Между тем, если вновь в качестве примера обратиться к криминалистическому, а вернее к комплексному обеспечению противодействия преступлениям несовершеннолетних и в отношении них, то не лишним будет отметить, что в разделе 2 Национальной стратегии действий в интересах детей на 2012-2017 годы, утвержденной Указом Президента России от 2 июня 2012 года указано: «В Российской Федерации формирование и реализация политики в области детства должна основываться на использовании последних достижений науки, современных технологий...» (здесь и далее выделено мной Ю.Г.). А в разделе 3 предписано: «Создание и рас-

\footnotetext{
${ }^{4}$ См., например: Памятка: «Предупреждение коррупции и защита от незаконного обвинения в коррупционномпреступлении»: автор-составитель Гармаев Ю.П. / Сайт Министерства социальной защиты населения Республики Бурятия. Режим доступа: http://minsoc-buryatia.ru/anticorruption/4802/ Дата обращения: 11.10.2013. Подобные памятки, адаптируемые мною специально для соответствующей категории служащих, последние 5 лет широко распространяются в рамках занятий по противодействию коррупции в различных государственных и иных организациях.
} 
пространение информации о правах ребенка, адаптированной для детей, родителей, учителей, специалистов, работающих с детьми и в интересах детей, через средства массовой информации, сеть «Интернет», организации и учреждения для детей».

$\mathrm{C}$ «последними достижениями науки, современных технологий» применительно к инструментарию наук антикриминального цикла все кажется вполне ясно. Если процесс их внедрения оценить одним словом, то это будет слово: «Отстаем...». Далее, полагал бы, что термин «адаптированность» в контексте Национальной стратегии означает как раз изложенное выше краткость, простота изложения рекомендаций и представление их не только и не столько в бумажной, но в мультимедийной форме, с применением современных технологий, в том числе, мобильных, с использованием ресурсов Интернета.

Современные подростки и молодежь, взрослые люди возраста 25-55 лет - то есть самая активная часть населения, в настоящее время пользуются стационарными и мобильными компьютерами (ноутбуками, планшетами и др.), устройствами для чтения электронных книг и др. как на работе, так и дома, а также в общественном транспорте, в иных поездках. До половины граждан ежедневно используют сложную мобильную телефонную технику - смартфоны и коммуникаторы на операционных системах «iOS», «Android», «Windows mobile» и др., на которых установлено современное программное обеспечение, позволяющее хоть дома, хоть в общественном транспорте читать и слушать книги, просматривать фото, презентации и слайд-шоу, видео и прочий контент.

Глубоко убежден, что все науки антикриминального цикла должны сами двигаться навстречу своему «конечному потребителю», разрабатывая и внедряя «продукцию» в различных вариантах в зависимости не от сложившихся внутринаучных традиций, а от тенденций потребления, характеристики типичного конечного потребителя. «Нетрадиционный» тип последнего, формирование рекомендаций для него, причем преимущественно в интерактивной, мультимедийной, стационарной, плюс мобильной форме, с междисциплинарным содержанием, должно стать приоритетным направлением прикладных разработок названных наук.

Не стоит ждать неких абстрактных IT-специалистов, которые «придут, возьмут и превратят наши бумажные книги в алгоритмы и програм- мы». Не придут... Это невозможно даже чисто технически. Нужно активное творческое взаимодействие между учеными - разработчиками разных наук антикриминального цикла с подключением в творческие коллективы IT-специалистов и даже целых компаний таковых, как это сделали работники ГУ криминалистики СК РФ совместно с компанией «Фундаментальные системы анализа» в рамках упомянутого выше проекта. Причем инициатива преимущественно должна исходить именно от нас - представителей научного сообщества, а не от специалистов по компьютерным технологиям.

Итак, можно и нужно создавать системы межотраслевых рекомендаций в виде кратких, но емких по содержанию, с красивым, ярким пользовательским интерфейсом программ типа Памяток, «Кратких руководств по...».

Попробуем предложить наименование и примерное содержание такого рода разработки с указанием на источники рекомендаций (виды наук):

\section{ПАМЯТКА ШКОЛЬНИКУ (УЧАЩЕМУСЯ ПТУ, СТУДЕНТУ) «ЧТО ДЕЛАТЬ, ЕСЛИ ТЕБЯ ПЫТАЮТСЯ ВОВЛЕЧЬ В НЕЗАКОННЫЙ ОБОРОТ НАРКОТИКОВ»} мы $^{1}$ :

Примерное содержание памятки-програм-

- Вводная часть: мотивационное воздействие и описание программы; краткие, эмоционально окрашенные пояснения типа: «Зачем тебе, друг, это надо...»; данные о структуре рекомендаций, назначении разделов, отзывы, оценки пользователей и т.п. ${ }^{2}$

- типичные ситуации вовлечения; кто может вовлечь (друзья, одноклассники, однокурсники, взрослые люди определенных социальных групп, и т.п.), с какими целями, какими способами (уговоры, шантаж, подкуп, дружеские чувства и т.п.); как им противодействовать; какими бывают наркотические средства, как они выглядят и т.д.; что делать, если тебя все-таки уже вовлекли в потребление наркотиков, в пре-

\footnotetext{
${ }^{1}$ Можно и нужно сделать отдельно и бумажную памятку, и программу. Но приоритет, думается, за последней.

${ }^{2}$ Методологию создания данного и некоторых иных информационных блоков-рекомендаций полезно заимствовать у наук маркетинга и менеджмента, у широкого класса дисциплин под общим наименованием «Информационные технологии».
} 
ступную деятельность; как противостоять распространенным формам противозаконной провокации, подстрекательства к преступлениям (криминалистические рекомендации, а также данные наук судебно-экспертной деятельности, оперативно-розыскной деятельности (в несекретной части)

- как квалифицируются соответствующие деяния, какие наказания предусмотрены уголовным законом; каковы не только правовые, но и иные последствия привлечения к уголовной ответственности (включая ситуации осуждения к лишению свободы, условного осуждения, прекращения уголовного преследования по нереабилитирующему основанию и т. п.); последствия для здоровья, дальнейшей учебы, будущей карьеры, для родителей, для иных разнообразных сторон жизни несовершеннолетнего (уголовно-правовые и иные рекомендации);

- $\quad$ краткая характеристика наркопреступности в регионе, коэффициенты преступности; по некоторым видам преступлений весьма уместна краткая региональная виктимологическая характеристика (криминологические рекомендации);

- $\quad$ какие государственные органы и иные организации страны ведут профилактическую деятельность, а какие - борьбу с данными преступлениями; как и куда можно обратиться за помощью; какая помощь может быть оказана (разноотраслевые рекомендации);

- как уберечь свое здоровье, справиться со стрессом, вызванным попыткой вовлечения (состоявшимся вовлечением) в преступную деятельность; как найти общий язык с родителями, иными членами семьи, товарищами в типичных сложных жизненных ситуациях (криминалистические, медицинские и психологические рекомендации);

И многое другое. Но повторюсь: все должно быть изложено в краткой и доступной для данного типа конечного потребителя форме. Должны приветствоваться анимация, фотографии и слайд-шоу, видеоролики (в том числе, устрашающие, как на пачках сигарет) и т. п. Текст должен излагаться с использованием индивидуального,

\footnotetext{
1 Здесь уместно важное ограничение - недопустимость «рекламы» преступной деятельности, «инструкций по совершению преступлений», а также завуалированных рекомендаций о том, как уйти от ответственности за их совершение. Автором предпринята попытка разработки методологии такого рода ограничений.
}

дружеского обращения типа: «Дорогой друг! Конечно, не дай бог, но предположим с тобой приключилась вот такая неприятность...».

Разумеется, подобные памятки и краткие руководства можно и нужно разрабатывать, внедрять адресно и для родителей, учителей и т.д. Памятки для взрослых, вероятно, в значительно части будут повторять содержание выше предложенной - для несовершеннолетних. Но в разработках для первых, кроме прочего, например, можно уделить внимание тому, как составить доверительный разговор просветительского, предупредительного характера между несовершеннолетним и близкими людьми / иными лицами; как распознать признаки вовлеченности скрытного ребенка в незаконный оборот наркотиков, иной криминал, а также патологической игромании и т. п.; как провести иные виды бесед, куда и как обратиться за помощью и т.п. (криминалистические рекомендации, педагогика, психология, и т.п.).

Заметим, несмотря на всю универсальность и синтетический характер науки криминалистики, субъективно вряд ли подобного рода междисциплинарные «продукты» под силу создать одному или нескольким разработчикам - только криминалистам. Вполне солидарен с неявно выраженной грустью В. Ю. Шепитько, угадывающейся в его риторическом: «... где взять специалиста, знающего и теорию криминалистики и практику борьбы с преступностью... Причем, презюмируется, что специалист в области криминалистики знает уголовное право, процесс, судопроизводство на высоком уровне, с учетом изменений в действующем законодательстве... имеет познания в сфере естественно-технических наук и судебных экспертиз» ${ }^{2}$. Не будем преувеличивать наших возможностей - все-таки нужны творческие коллективы разноотраслевых специалистов.

Не только в России, но и в других странах необходимо вложить государственные средства, привлечь инвестиции в то, чтобы подобные программные продукты распространялись бесплатно, например: в основных Интернет-магазинах: «Apple AppStore», «Google Play», «Windows Store» и др.; по рекламным ссылкам (баннерам) в известных международных соцсетях (Facebook,

\footnotetext{
${ }^{2}$ Шепитько В. Ю. Криминалистика XXI века: предмет познания, задачи и тенденции в новых условиях // Современное состояние и развитие криминалистики. Сб. науч. трудов / Под ред. Н. П. Яблокова и В. Ю. Шепитько.Х.: «Апостиль», 2012.- С. 53.
} 
Google+, LiveJournal, Twitter, «Вконтакте», «Одноклассники» и другие); на иных популярных в соответствующей потребительной среде Интернет-ресурсах; в «пакетных предложениях» с компьютерными играми, другими популярными программными продуктами на предприятиях, в организациях и т.д.

Повторюсь, эти программы можно и нужно создавать и распространять так, чтобы их можно было изучить бесплатно, очень быстро, найдя намеренно или наткнувшись случайно («бродя по Сети») на телефоне, планшете в общественном транспорте, прослушать в автомобильной «пробке» (например, водителю), в метро, открыть во всплывающих окнах типа нынешней навязчивой рекламы товаров и услуг в Интернете, и т.п.

Итак, пора юридической науке идти прямой дорогой навстречу современной мультимедийной цифровой среде, к людям, в том числе, к не юристам, «потребляющим» информацию гигабайтами и в краткие сроки, в основном «между делом».

Есть все основания полагать, что внедрение в науки антикриминального цикла не просто направления, а некой парадигмы приоритета создания прикладных разноотраслевых мультимедийных разработок типа кратких памяток, руководств и программ, соответствующее уточнение концептуальных подходов к формированию и представлению учебных и практических рекомендаций, к обучению различных потенциальных потребителей - все это позволит сделать важный шаг к сближению науки с практикой, к модернизации наук антикриминального цикла (впрочем, как и иных юридических и неюридических наук), а главное - к повышению эффективности правоприменения, к росту правосознания населения.

\section{Библиография}

1. Белкин Р. С. Курс криминалистики: учеб. пособие для вузов. - 3-е изд., доп. - М., 2001.

2. Боровских Р.Н. Актуальные проблемы противодействия преступлениям в сфере страхования в России. Видеолекция / Сайт Международной ассоциации содействия правосудию (МАСП). Режим доступа: http://www.iuaj.net/node/1325. Дата обращения: 11.10.2013.

3. Вележев С. С. Консолидация теории и практики в решении проблем, связанных с юридической ответственностью и наказанием // Администратор суда.— 2011. - № 1.

4. Гвоздева И.С. Использование специальных знаний при расследовании групповых корыстно-насильственных преступлений несовершеннолетних: Дис. ... канд. юр. наук: 12.00.09. - М., 2008.

5. Елинский В. И., Ашимов Ф. М. Виртуальный осмотр места происшествия-инновационный метод повышения профессионального мастерства следователей // Российский следователь. - 2013.— № 4.

6. Ищенко Е. П., Жижина М.В. Современные представления о предмете науки криминалистики // Ситуационный подход в юридической науке и правоприменительной деятельности: Мат-лы межд. науч. — практ.конф. / под ред. Т. С. Волчецкой. — Калининград: Изд-во БФУ имени И. Канта, 2012.

7. Макаренко И.А. Криминалистическое учение о личности несовершеннолетнего обвиняемого: Дис. ... доктора юр. наук. 12.00.09.- Саратов, 2007.

8. Памятка: «Предупреждение коррупции и защита от незаконного обвинения в коррупционном преступлении»: автор-составитель Гармаев Ю. П. / Сайт Министерства социальной защиты населения Республики Бурятия. Режим доступа: http://minsoc-buryatia.ru/anticorruption/4802/ Дата обращения: 11.10.2013.

9. Подольный Н. А. Теоретические и практические основы раскрытия и расследования преступлений, совершённых молодёжными организованными группировками: Дис. ... доктора юр. наук: 12.00.09.- M, 2008.

10. Смахтин Е. В. Криминалистика в системе юридических наук уголовно-правового цикла: теория и практика: Дисс... доктора юрид. наук. 12.00.09. - Тюмень. 2010.

11. Соя-Серко Л. А. Программирование расследования // Социалистическая законность. - 1980.№ 1.

12. Третьяков Ю.С. Процессуальные и тактические основы рассмотрения дел о преступлениях несовершеннолетних мировым судьей: Дис. ... канд. юр. наук: 12.00.09. - М., 2009.

13. Уголовное право Российской Федерации. Общая часть: Учебник для вузов / под ред. В. С. Комиссарова, Н.Е. Крыловой, И. М. Тяжковой.- М., 2012.

14. Шаталов А.С. Криминалистические алгоритмы и программы. Теория. Проблемы. Прикладные аспекты. (Научное издание) - М., 2000. 
15. Шепитько В. Ю. Криминалистика XXI века: предмет познания, задачи и тенденции в новых условиях // Современное состояние и развитие криминалистики. Сб. науч. трудов / под ред. Н. П. Яблокова и В. Ю. Шепитько. - Х., 2012.

16. Шепитько В. Ю. Криминалистика XXI века: предмет познания, задачи и тенденции в новых условиях // Современное состояние и развитие криминалистики. Сб. науч. трудов / Под ред. Н. П. Яблокова и В. Ю. Шепитько.-Х., 2012.

17. Эйсман А.А. Теоретические вопросы программирования расследования // Вопросы борьбы с преступностью.- М., 1987. Вып. 45.

18. Эксархопуло А. А. Криминалистика: Учебник.-СПб., 2009.

\section{References (transliterated)}

1. Belkin R. S. Kurs kriminalistiki: ucheb. posobie dlya vuzov. - 3-e izd., dop.-M., 2001.

2. Borovskikh R. N. Aktual'nye problemy protivodeistviya prestupleniyam v sfere strakhovaniya v Rossii. Videolektsiya / Sait Mezhdunarodnoi assotsiatsii sodeistviya pravosudiyu (MASP). Rezhim dostupa: http://www.iuaj.net/node/1325. Data obrashcheniya: 11.10.2013.

3. Velezhev S. S. Konsolidatsiya teorii i praktiki v reshenii problem, svyazannykh s yuridicheskoi otvetstvennost'yu i nakazaniem // Administrator suda. - 2011. — № 1 .

4. Gvozdeva I. S. Ispol'zovanie spetsial'nykh znanii pri rassledovanii gruppovykh korystno-nasil'stvennykh prestuplenii nesovershennoletnikh: Dis. ... kand. yur. nauk: 12.00.09.- M., 2008.

5. Elinskii V. I., Ashimov F. M. Virtual'nyi osmotr mesta proisshestviya-innovatsionnyi metod povysheniya professional'nogo masterstva sledovatelei // Rossiiskii sledovatel».—2013.—№ 4 .

6. Ishchenko E. P., Zhizhina M. V. Sovremennye predstavleniya o predmete nauki kriminalistiki // Situatsionnyi podkhod v yuridicheskoi nauke i pravoprimenitel'noi deyatel'nosti: Mat-ly mezhd. nauch.prakt.konf. / pod red. T. S. Volchetskoi. - Kaliningrad: Izd-vo BFU imeni I. Kanta, 2012.

7. Makarenko I. A. Kriminalisticheskoe uchenie o lichnosti nesovershennoletnego obvinyaemogo: Dis.... doktora yur. nauk. 12.00.09. - Saratov, 2007.

8. Pamyatka: «Preduprezhdenie korruptsii i zashchita ot nezakonnogo obvineniya v korruptsionnom prestuplenii»: avtor-sostavitel» Garmaev Yu. P. / Sait Ministerstva sotsial'noi zashchity naseleniya Respubliki Buryatiya. Rezhim dostupa: http://minsoc-buryatia.ru/anticorruption/4802/ Data obrashcheniya: 11.10.2013.

9. Podol'nyi N. A. Teoreticheskie i prakticheskie osnovy raskrytiya i rassledovaniya prestuplenii, sovershennykh molodezhnymi organizovannymi gruppirovkami: Dis. ... doktora yur. nauk: 12.00.09. M, 2008.

10. Smakhtin E. V. Kriminalistika v sisteme yuridicheskikh nauk ugolovno-pravovogo tsikla: teoriya i praktika: Diss... doktora yurid. nauk. 12.00.09. — Tyumen». 2010.

11. Soya-Serko L. A. Programmirovanie rassledovaniya // Sotsialisticheskaya zakonnost».—1980.—№ 1.

12. Tret'yakov Yu.S. Protsessual'nye i takticheskie osnovy rassmotreniya del o prestupleniyakh nesovershennoletnikh mirovym sud'ei: Dis. ... kand. yur. nauk: 12.00.09. - M., 2009.

13. Ugolovnoe pravo Rossiiskoi Federatsii. Obshchaya chast': Uchebnik dlya vuzov / pod red. V.S. Komissarova, N. E. Krylovoi, I. M. Tyazhkovoi.-M., 2012.

14. Shatalov A. S. Kriminalisticheskie algoritmy i programmy. Teoriya. Problemy. Prikladnye aspekty. (Nauchnoe izdanie) - M., 2000.

15. Shepit'ko V. Yu. Kriminalistika KhKhI veka: predmet poznaniya, zadachi i tendentsii v novykh usloviyakh // Sovremennoe sostoyanie i razvitie kriminalistiki. Sb. nauch. trudov/ pod red. N. P. Yablokova i V. Yu. Shepit'ko.-Kh., 2012.

16. Shepit'ko V. Yu. Kriminalistika KhKhI veka: predmet poznaniya, zadachi i tendentsii v novykh usloviyakh // Sovremennoe sostoyanie i razvitie kriminalistiki. Sb. nauch. trudov / Pod red. N. P. Yablokova i V. Yu. Shepit'ko. - Kh., 2012.

17. Eisman A. A. Teoreticheskie voprosy programmirovaniya rassledovaniya// Voprosy bor'by s prestupnost'yu. - M., 1987. Vyp. 45.

18. Eksarkhopulo A. A. Kriminalistika: Uchebnik. — SPb., 2009. 